\title{
Perilaku Menyimpang Ilegal Fishing
}

\author{
Risnawati \\ Marham Muhammadiyah \\ Universitas Muhammadiyah Makassar \\ marhammuhammdiyah@unismuh.ac.id \\ Risfaisal \\ Universitas Muhammadiyah Makassar \\ rsisfaisal@unismuh.ac.id
}

\begin{abstract}
ABSTRAK
Penelitian ini bertujuan untuk mengetahui bagaimanakah perilaku nelayan terhadap kegiatan penangkapan ikan dengan menggunakan bahan peledak di Taka Bonerate Kabupaten Kepulauan selayar dan untuk mengetahui dampak perilaku nelayan terhadap ekosistem terumbu karang di Taka Bonerate Kabupaten Kepulauan selayar. Penelitian ini merupakan penelitian lapangan yang bersifat deskriptif kualitatif, karena penelitian ini menggambarkan keadaan kompleks, dinamis dan penuh makna, selain itu penelitian bermaksud memahami situasi sosial secara mendalam. Adapun teknik pengumpulan data dengan cara menggunakan studi pustaka dengan observasi langsung dan wawancara untuk fakta-fakta berdasarkan pengamatan peneliti serta dokumentasi berupa gambar dan juga foto. Hasil penelitian menggambarkan bahwa perilaku menyimpang (studi kasus illegal fishing di taka bonerate kabupaten kepulauan selayar). Perilaku menyimpang yaitu illegal fishing yang dimaksud adalah pengkapang ikan dengan menggunakan bahan peledak bom, sianida dan pembiusan, dan adapun dampak perilaku nelayan terhadap ekosistem terumbu karang di taka bonerate kabupaten kepualauan selayar adalah akibat rendahnya tingkat pendidikan sehingga pengetahuan tentang kerusakan ekosistem terumbu karangpun tidak dapat diketahui, penangkapan ikan dengan menggunkan bahan peledak juga berdampak terhadap keselamatan nyawa pelaku sendiri, ikan yang didapat tidak segar dan juga cepat busuk. Dengan melakukan penangkapan ikan menggunakan bahan peledak dapat mempercepat banyaknya penghasilan sehingga masyarakatpun tetap untuk melakukan pemboman.
\end{abstract}

Kata Kunci : Ilegal fishing, Masyarakat, Perilaku Menyimpang.

\section{PENDAHULUAN}

Hukum itu bukan tujuan, akan tetapi hanya merupakan jembatan atau alat yang akan membawa kita kepada ide yang dicita-citakan. Dengan demikian, hukum seyogyanya harus senantiasa mengacu pada cita-cita masyarakat bangsa. Hukum harus dibangun untuk tujuan-tujuan mengakhiri suatu tatanan sosial yang tidak adil dan menindas hak-hak asasi manusia. Sebagaimana diketahui bahwa Indonesia merupakan negara kepulauan yang sebagian besar luas wilayahnya terdiri dari perairan, sehingga dengan sendirinya mata pencaharian penduduk adalah nelayan. Oleh karena itu, dengan tujuan peningkatan taraf hidup, para nelayan tidak jarang melakukan hal-hal yang 
dilarang yang bertentangan dengan hukum. Para nelayan yang ada di Taka Bonerate Kabupaten Kepulauan Selayar masih sering melakukan penangkapan ikan dengan menggunakan bahan peledak, hal ini sangat berbahaya bagi diri pelaku juga terhadap lingkungan dan habitat laut serta ekosistem yang ada disekitarnya, bahkan dapat musnah. Sebagai negara yang memiliki perairan yang luas, tentunya dibutuhkan jaminan hukum bagi keamanan dan kelestarian ekosistem laut agar dapat memberikan manfaat berkelanjutan serta dapat menjaga wibawa negara dan bangsa dari setiap ancaman baik dari dalam maupun dari luar terhadap kedaulatan wilayah perairan, oleh karena itu kepastian hukum merupakan suatu kondisi yang mutlak diperlukan. Undang-undang Nomor 45 Tahun 2009 tentang Perikanan Pembaruan atas Undang-undang Nomor 31 Tahun 2004 tentang Perikanan, telah memberikan kepastian, hukum dan kejelasan bagi penegak hukum atas tindak pidana dibidang perikanan. Dalam meningkatkan efisiensi dan efektifitas penegakan hukum terhadap tindak pidana dibidang perikanan, telah diatur mengenai pembentukan pengadilan perikanan dilingkungan peradilan umum. Walaupun penangkapan ikan dengan menggunakan bahan peledak adalah suatu perbuatan terlarang yang bertentangan dengan peraturan hukum yang berlaku, akan tetapi dalam kenyataannya di wilayah perairan Taka Bonerate Kabupaten Kepulauan Selayar, masih sering terjadi penangkapan ikan secara illegal dengan cara menggunakan bahan peledak oleh para nelayan. Terumbu karang di Taka Bonerate Kabupaten Kepulauan Selayar yang dulunya indah dan dijuluki sebagai terumbu karang terindah ke tiga di dunia ini sudah hancur akibat ulah masyarakatnya sendiri, sehingga biota laut pun tidak punya tempat tinggal lagi karena terumbu karangnya telah di hancurkan dan di rusak akibat penangkapan ikan dengan menggunakan bahan peledak bom, sianida dan pembiusan.

Sebagaimana yang telah dipaparkan pada masalah di atas, dimana secara umum masyarakat pesisir (nelayan) terutama yang diindikasikan sebagi pelaku penangkapan ikan dengan menggunakan bahan peledak tersebut merupakan suatu perbuatan terlarang yang bertentangan dengan peraturan hukum yang berlaku dan tidak mengetahui tentang pentingnya ekosistem terumbu karang terbatas.

\section{LANDASAN TEORI}

Menurut Robert M. Z. Lawang. Penyimpangan perilaku adalah semua tindakan yang menyimpang dari norma yang berlaku dalam sistem sosial dan menimbulkan usaha dari mereka yang berwenang dalam sitem itu untuk memperbaiki perilaku menyimpang. Menurut James W. Van Der Zanden. Perilaku menyimpang yaitu perilaku yang bagi 
sebagian orang dianggap sebagai sesuatu yang tercela dan di luar batas toleransi. Menurut Soerjono Soekanto. Perilaku menyimpang adalah penyimpangan terhadap kaidah-kaidah dan nilai-nilai dalam masyarakat. Menurut John J. Macionis. Perilakun menyimpangan adalah pelanggaran terhadap norma-norma dalam masyarakat. Menurut James W. Van Der Zanden, faktor penyimpangan sosial dibagi menjadi tiga yaitu: (1) Longgar/tidaknya nilai dan norma. longgarnya nilai dan norma disuatu daerah akan berdampak pada perilaku menyimpang dalam masyarakat. (2) Sosialisasi yang tidak sempurna. Ketika seseorang dalam proses sosialisasinya dalam keluarga tidak sempurna, maka tak jarang seorang anak akan melakukan tindakan menyimpang. (3) Sosialisasi sub kebudayaan yang menyimpang. Meski sosialisasi dalam keluarga sudah baik, tetapi ketika mendapatkan sub budaya yang berbeda dari keluarga atau pengaruh dari budaya luar akan berdampak pada tindakan menyimpang. Dari penjelasan di atas dapat disimpulkan bahwa faktor-faktor yang mempengaruhi perilaku menyimpang adalah: 1) Pertentangan antara norma kelompok dengan norma masyarakat, 2) Tidak mempunyai seseorang sebagai panutan dalam memahami dan meresapi tata nilai atau norma-norma yang berlaku di masyarakat, 3) Pengaruh lingkungan kehidupan sosial yang tidak baik, 4) Pertentangan antar agen sosialisasi Pengaruh fisik dan jiwa seseorang, 5) Proses bersosialisasi yang negatif. 6) Ketidak adilan. Menurut Lemert (1951), Penyimpangan dibagi menjadi dua bentuk: a) Penyimpangan Primer (Primary Deviation). Penyimpangan yang dilakukan seseorang akan tetapi si pelaku masih dapat diterima masyarakat. b) Penyimpangan Sekunder (secondary deviation) Penyimpangan yang berupa perbuatan yang dilakukan seseorang yang secara umum dikenal sebagai perilaku menyimpang. c) Berdasarkan pelaku penyimpangan, d) Penyimpangan individu (individual deviation). Penyimpangan jenis ini dilakukan secara perorangan tanpa campur tangan orang lain dan berupa pelanggaran terhadap norma-norma suatu kebudayaan yang telah mapan, e) Penyimpangan kelompok (individual deviation). Penyimpangan yang dilakukan secara bersama-sama atau secara berkelompok dengan melanggar norma-norma yang berlaku dalam masyarakat. Penyimpangan yang dilakukan kelompok, umumnya sebagai akibat pengaruh pergaulan/teman, f) Penyimpangan campuran (mixture of both deviation) Penyimpangan ini diawali oleh individu, selanjutnya memengaruhi orang lain agar ikut dalam penyimpangan. 


\section{METODE PENELITIAN}

Jenis penelitian yang digunakan adalah penelitian kualitatif dengan metode analisis deskriptif yang bertujuan mengetahui perilaku nelayan terhadap penangkapan ikan dengan cara illegal dan dampak illegal fishing yang terdapat pada kampung Taka Bonerate Kabupaten Kepulauan Selayar. Informan ditentukan secara purposive sampling, teknik pengumpulan data yaitu studi pustaka, observasi langsung, wawancara dan dokumentasi berupa gambar dan foto, kemudian dianalisi melalui teknik analisis data kualitatif melalui analisis presentase berdasarkan hasil penelitian kemudian di tafsirkan dengan kalimat yang bersifat kualitatif atau penjelasan. Hasil analisa data tersebut kemudian dijadikan hasil kesimpulan akhir dalam penelitian dan menggunakan teknik keabsahan data kepercayaan dengan teknik ketekunan pengamatan, triangulasi, kecukupan referensi, kebergantungan dan kepastian.

\section{PEMBAHASAN}

Kerusakan terumbu karang Taka Bonerate Kabupaten Kepulauan Selayar yang sangat parah tersebut, dijelaskan bahwa hal itu akibat perilaku nelayan-nelayan yang dari dulu terbiasa memakai bom ikan. Meski sudah lama mengetahui bahwa pemakaian bom ikan adalah terlarang, mereka cukup leluasa mempergunakan karena keterbatasan kemampuan pemerintah untuk mengawasi aktivitas penangkapan ikan di laut. Selain penggunaan bom ikan, kerusakan terumbu karang juga disebabkan oleh aktivitas racun sianida dan pembiusan. Kerusakan terumbu karang ini menyebabkan ikan menjadi langka di perairan Taka Bonerate Kabupaten Kepulauan Selayar. Hal ini merugikan nelayan sendiri, dimana kelangsungan usaha mereka menjadi terancam. Ekosistem terumbu karang juga memegang peranan penting terutama bagi perikanan tradisional berskala kecil, terutama bagi negara kepulauan seperti Indonesia dan khusunya bagi kasawan Taka Bonerate. Nilai dari perikanan kecil ini seringkali kurang diperhitungkan karena sebagian besar nelayan yang menangkap hanya untuk pemenuhan kebutuhan hidupnya tidak tercatat dan juga karena berbagai macam hal, namun demikian diperkirakan secara kasarnya bahwa peranan lestari dari perairan terumbu karang dengan kedalaman kurang dari 30 meter adalah sekitar 15 ton per $\mathrm{km}$. Kegiatan penangkapan yang dilakukan nelayan seperti menggunakan bahan peledak dan bahan beracun, bertentangan dengan kode etik penangkapan. Kegiatan ini umumnya bersifat merugikan bagi sumber daya perairan yang ada. Kegiatan ini semata-mata hanya akan memberikan dampak yang kurang baik bagi ekosistem perairan, akan tetapi memberikan keuntungan yang besar bagi 
nelayan. Dalam kegiatan penangkapan yang dilakukan nelayan dengan cara dan alat tangkap yang bersifat merusak yang dilakukan khususnya oleh nelayan tradisional. Untuk menangkap sebanyak-banyaknya ikan karang yang banyak, digolongkan kedalam kegiatan illegal fishing. Karena kegiatan penangkapan yang dilakukan semata-mata memberikan keuntungan hanya untuk nelayan tersebut, dan berdampak kerusakan untuk ekosistem karang. Kegiatan yang umumnya dilakukan nelayan dalam melakukan penangkapan dan termasuk kedalam kegiatan illegal fishing adalah penggunaan alat tangkap yang dapat merusak ekosistem seperti kegiatan penangkapan dengan pemboman, penangkapan dengan menggunakan racun sianida dan pembiusan yang di lakukan di Kawasan Taka Bonerate Kabupaten Kepulauan Selayar. Selain itu perilaku nelayan yang ada di Taka Bonerate telah berkontribusi cukup besar terhadap kerusakan terumbu karang, seperti penangkapan ikan dengan bahan peledak bom. Bom ikan biasanya terbuat dari potassium nitrate, batu kerikil, pupuk dan minyak tanah yang dimasukkan dalam botol-botol mulai botol minuman suplemen, botol bir, dan botol minuman keras. Berat setiap botol kurang lebih setengah hingga dua kilogram. Setiap botol bom ini memiliki spesifikasi berbeda-beda. Botol bom yang terbuat dari minuman suplemen umumnya digunakan mengebom ikan dalam jumlah yang kecil mulai 1-5 kuintal ikan. Sedangkan botol bom yang terbuat dari botol bir dipakai untuk mengebom ikan dalam jumlah yang besar hingga berton-ton. Satu bom seukuran botol minuman suplemen mampu mematikan ikan hingga radius 15 meter dari titik pengeboman sedangkan yang seukuran botol bir radiusnya 50 meter dari titik pengeboman. Dalam kaitannya dengan perilaku nelayan terhadap penangkapan ikan dengan menggunakan bahan peledak bom, racun sianida dan pembiusan dihubungkan dengan pengertian bahan peledak, maka perilaku nelayan di Taka Bonerate Kabupaten Kepulauan Selayar menunjukkan bahwa kegiatan yang nelayan lakukan itu benar-benar merusak dan berdampak buruk baik bagi diri nelayan sendiri maupun ekosistem terumbu karang, biota laut dan lain sebagainya. Masyarakat nelayan menyadari dengan kerusakan yang dilakukan tetapi belum bisa meninggalkan pekerjaan tersebut karena dengan tidak adanya pekerjaan lain yang bisa dilakukan dan yang melebihi penghasilannya dari kegiatan penangkapan ikan dengan menggunakan bahan peledak. Dilihat dari jenis illegal fishing maka perilaku nelayan di Taka Bonerate termasuk dalam jenis illegal fishing yang pertama dan kedua yaitu penangkapan ikan dengan menggunakan bahan peledak bom, dan pembiusan. Dampak dari penggunaan bom ikan yang dilakukan masyarakat nelayan tersebut dengan adanya getaran yang cukup keras yaitu rusak/hancurnya terumbu karang, ekosistem perairan, dan habitat laut yang 
lain dan butuh waktu yang cukup lama untuk dapat kembali kekeadaan semula. Penangkapan ikan dengan pembiusan yang dilakukan nelayan di Taka Bonerate dengan cara menyelam ke dalam laut sampai dengan kedalaman kira-kira antara 5 sampai 10 meter dengan cara menyemprotkan bahan-bahan kimia potassium ke dalam lubanglubang karang, yang terdapat ikan yang sementara memangsa plankton-plankton ikan kecil lainnya.

Kestabilan ekosistem laut, pengeboman ikan pada mulanya menggunakan bahan peledak komersial berkembang dan cenderung membuat bahan peledak sendiri dengan menggunakan pupuk kimia, setiap bom beratnya kurang lebih $1 \mathrm{~kg}$ dan ledakannya membunuh ikan dalam radius 15 - 20 meter, terumbu seluas $500 \mathrm{~m} 2$ dan menciptakan lubang di terumbu dengan diameter 3-4 meter, dan pengebom mencari ikan yang hidup berkelompok (ikan bibir tebal, kerapu, ekor kuning, kakap tua dan surgeon) yang menjadi sasaran utamanya (Asbar, 2009). Itu semua membuat ekosistem di bawah laut menjadi tidak stabil, bahkan banyak sekali makhluk hidup di bawah laut yang sudah hampir punah. Mungkin mereka belum menyadari pentingnya sebuah keberlangsungan terumbu karang bagi ikan. Karena jika terumbu karang hancur maka ikan tidak memiliki tempat tinggal untuk bernaung dan mencari makan. Karena itulah, seharusnya Polair di setiap daerah gencar melakukan sweeping bagi siapapun yang membawa dan menggunakan bom untuk ikan. Hal ini dilakukan agar terumbu karang di daerah kawasan timur tetap terjaga. Walaupun penangkapan ikan dengan menggunakan bahan peledak itu merupakan hal yang dilarang tetapi masih banyak masarakat nelayan di Taka Bonerate Kabupaten Kepulauan Selayar yang melakukannya, karena tidak adanya kesadaran dengan akibat yang akan ditimbulkannya. Penggunaan bahan peledak dalam penangkapan ikan di sekitar Kawasan Taka Bonerate Kabupaten Kepulauan Selayar selain rusaknya terumbu karang yang ada di sekitar lokasi peledakan, juga dapat menyebabkan kematian biota lain yang bukan merupakan sasaran penangkapan. Karena tidak adanya pekerjaan lain selain penangkapan ikan yang dilakukan oleh masyarakat nelayan di Taka Bonerate kabupaten Kepulauan Selayar sehingga kagiatan penangkapan ikan dengan menggunakan bahan peledak masih meraja lela dan juga karena pemboman atau penangkapan ikan dengan menggunakan bahan peledak banyak penghasilannya.

Dampak dari penggunaan bom ikan tersebut dengan adanya getaran yang cukup keras yaitu rusak/hancurnya terumbu karang, ekosistem perairan, dan habitat laut yang lain dan butuh waktu yang cukup lama untuk dapat kembali kekeadaan semula. Kegiatan pembiusan dapat berdampak pada kerusakan terumbu karang, terganggunya ekosistem 
perairan, dan musnahnya biota laut lainnya yang mengancam kerusakan permanen sehingga berpengaruh pada kelangsungan dan kegunaan serta kelestarian lingkungan perairan/laut di masa yang akan datang. Menangkap ikan dengan menggunakan bahan kimia yang dilakukan oleh sebagian besar nelayan di Taka Bonerate Kabupaten Kepulauan selayar yang melakukan penangkapan ikan di laut/perairan ini dilakukan oleh nelayan secara perorangan/kelompok nelayan yang telah dimodali oleh punggawa yang telah mempersiapkan kebutuhan nelayan dalam kegiatan penangkapan tersebut. Banyaknya dampak yang ditimbulkan masyarakat nelayan di taka Bonerate Kabupaten Kepulauan selayar tetapi kegiatan penangkapan ikan dengan menggunakan bahan peledak bom maupun pembiusan masih meraja lela. Kehancuran terumbu karang akibat bom, karang-karang pecah dan terbalik akibat penggunaan bom ikan. Sementara tanda hitam pada karang merupakan indikasi sisa penggunaan potas atau racun kalium sianida dari para penangkap ikan. Kerusakan terumbu karang di wilayah kawasan Taka Bonerate akan berdampak pada populasi ikan yang hidupnya bergantung pada karang. Kerusakan terumbu karang juga menyebabkan populasi dan variasi spesies ikan di perairan Taka Bonerate Kabupaten Selayar berkurang. Sekarang nelayan harus pergi lebih jauh ke tengah laut untuk mencari ikan. Mencari ikan juga sudah tidak semudah dulu. Namun kegiatan-kegiatan yang menyebabkan kerusakan terumbu karang saat ini sudah berkurang. Aktivitas pemboman masih ada tetapi sedikit berkurang karena ikan masih sedikit. Ikan-ikan yang biasanya jadi umpan ini sedikit karena sudah habis dibom. Potensi perbaikan dengan adanya karang-karang kecil yang baru tumbuh. Terlihat dari karang baru yang tumbuh dan ikan-ikan kecil yang terlihat seperti ikan indikator yang memakan pucuk karang dan ikan target.

Keselamatan nelayan, nelayan sangat suka menangkap ikan dengan menggunakan bahan peledak supaya mendapat ikan yang banyak. padahal cara seperti itu sangat berbahaya bagi nelayan itu sendiri. Pengeboman ikan pada mulanya menggunakan bahan peledak komersial berkembang dan cenderung membuat bahan peledak sendiri dengan menggunakan pupuk kimia, setiap bom beratnya kurang lebih $1 \mathrm{~kg}$ dan ledakannya membunuh ikan dalam radius 15 - 20 meter, terumbu seluas $500 \mathrm{~m} 2$ dan menciptakan lubang di terumbu dengan diameter 3-4 meter, dan pengebom mencari ikan yang hidup berkelompok (ikan bibir tebal, kerapu, ekor kuning, kakap tua dan surgeon) yang menjadi sasaran utamanya (Asbar, 2009). Disamping itu, produk membahayakan konsumen, hasil tangkapan yang terbuang dampaknya minimum terhadap keanekaragam sumberdaya hayati dan tidak menangkap spesies yang dilindungi dan terancam punah dan 
diterima secara sosial. Kesehatan ikan yang ditangkap dengan menggunakan bahan peledak tidak segar, ikan yang ditangkap dengan menggunakan bahan peledak itu biasanya cepat busuk, sehingga sagat mudah dibedakan antara ikan hasil tangkapan yang normal. Keselamatan nelayan, nelayan sangat suka menangkap ikan dengan menggunakan bahan peledak supaya mendapat ikan yang banyak. padahal cara seperti itu sangat berbahaya bagi nelayan itu sendiri. Bom ikan sebenarnya sangat berbahaya bagi kelangsungan hidup biota laut. Ledakan yang dihasilkan dapat membunuh semua kehidupan yang ada di dalam laut hingga radius ribuan meter. Efek kejut yang ditimbulkan dari getaran tersebut akan menghancurkan dan mematikan terumbu karang dan ikan-ikan mulai dari telur hingga ikan dewasa. Hal ini jelas sangat merugikan, terutama menyangkut hancurnya terumbu karang. Karena terumbu karang itu sendiri merupakan tempat ikan mencari makan sekaligus rumah bagi ikan-ikan tersebut. Bila terumbu karang hancur ikan - ikan tidak mempunyai tempat mencari makan dan rumah, otomatis ikan yang ada akan hilang selamanya alias punah. Berikut sedikit paparan kaitan antara terumbu karang dan proses kehidupan kita di atas bumi ini. Terumbu karang adalah salah satu komponen rantai makanan dalam siklus daur hidup hewan di air laut sekaligus tameng atau benteng pertahanan daratan dari gempuran gelombang laut. Secara umum terumbu karang tersebut diperlukan dalam segala aspek sebagaimana yang di paparkan oleh Jacob J Herin dalam opininya (PK 19/08/2009) yaitu antara lain; sebagai penunjang berbagai macam kehidupan yang dibutuhkan dalam produksi makanan, kesehatan dan berbagai aspek dari kehidupan manusia dan juga dalam pembangunan yang berkelanjutan.

Teori Undercontrol/Consensus adalah teori dalam mengkaji prilaku menyimpang (pelanggaran) mendasarkan diri bahwa kita semua menyepakati isi serta berlakunya kaidah-kaidah mayarakat termasuk norma-norma hukum, social, moral dan lain-lain. Oleh karena itu merupakan kewajaran bila semua warga masyarakat mematuhi aturanaturan hukum tersebut. Konsekuensi dari kerangka dasar kajian teori ini, yaitu "Kenapa ada seseorang yang bisa menolak aturan sosial sementara hampir semuanya (masyarakat) menerima". Dalam kaitannya teori netralisasi dengan perilaku nelayan yang melakukan kegiatan penangkapan ikan dengan cara illegal yaitu orang-orang berperilaku menyimpang disebabkan karena adanya kecenderungan dikalangan masyarakat bahkan pemerintah sendiri seakan melegalkan yang sudah jelas illegal. Karena pemerintah juga dalam hal ini pemerintah setempat ikut andil dalam kegiatan penangkapan ikan dengan menggunakan bahan peledak yang merasionalkan norma-norma yang di dalamnya ada 
hukum yang berlaku. Terumbu karang melindungi pantai dari hempasan ombak dan keganasan badai, mencegah terjadinya erosi dan mendukung terbentuk pantai berpasir di samping juga melindungi berbagai macam pelabuhan. Terumbu karang merupakan sumber bahan baku untuk berbagai kegiatan manusia seperti antara lain batu karang dan pasir sebagai bahan bangunan, karang hitam (black corang) sebagai bahan perhiasan dan juga karang atau moluska yang hidup di ekosistem ini bisa dimanfaatkan sebagai bahan pengipas keindahan rumah. Ekosistem terumbu karang menyumbangkan berbagai biota lalut seperti ikan karang, moluska dan krustasea bagi berbagai kelompok masyarakat yang hidup disekitar kawasan pesisir, dan bersama dengan ekosistem pantai lainnya menyediakan makanan dan merupakan tempat berpijah bagi banyak jenis biota laut yang berpotensi komersial. Ekosistem terumbu karang juga memegang peranan penting terutama bagi perikanan tradisional berskala kecil, terutama bagi negara kepulauan seperti Indonesia. Nilai dari perikanan kecil ini seringkali kurang diperhitungkan karena sebagian besar nelayan yang menangkap hanya untuk pemenuhan kebutuhan hidupnya tidak tercatat dan juga karena berbagai macam hal, namun demikian diperkirakan secara kasarnya bahwa peranan lestari dari perairan terumbu karang dengan kedalaman kurang dari 30 meter adalah sekitar 15 ton per km (Murno \& Wiliams, 1985).

\section{KESIMPULAN}

Dari penelitian yang telah dilaksanakan di Taka Bonerate Kabupaten Kepulauan selayar tentang Ilegal Fishing/Penangkapan Ikan dengan Menggunakan Bahan Peledak, dapat disimpulkan bahwa:

1. Perilaku nelayan di Taka Bonerate Kabupaten Kepulauan Selayar menunjukkan bahwa kegiatan yang nelayan lakukan itu benar-benar merusak dan berdampak buruk baik bagi diri nelayan sendiri maupun ekosistem terumbu karang, biota laut dan lain sebagainya. Masyarakat nelayan menyadari dengan kerusakan yang dilakukan tetapi belum bisa meninggalkan pekerjaan tersebut karena tidak adanya pekerjaan lain yang bisa dilakukan dan yang melebihi penghasilannya dari kegiatan penangkapan ikan dengan menggunakan bahan peledak.

2. Dampak dari penggunaan bom dan pembiusan ikan yang dilakukan nelayan di Taka Bonerate tersebut dengan adanya getaran yang cukup keras yaitu rusak/hancurnya terumbu karang, ekosistem perairan, dan juga berdampak pada keselamatan nelayan, serta habitat laut yang lain dan butuh waktu yang cukup lama untuk dapat kembali kekeadaan semula. 


\section{DAFTAR PUSTAKA}

Dahuri, Rokhmin. (2003). Keanekaragaman Hayati Laut, Aset Pembangunan Berkelanjutan Indonesia. Jakarta: PT.Gramedia Pustaka Utama.

Fauzi, Akhmad. (2007). Kebijakan Perikanan Dan Kelautan. Jakarta: Gramedia.

Gufran H. Kordi. K., M. (2010). Ekosistem Terumbu Karang. Jakarta: PT. Rineka Cipta.

Harahap, Mustafa Djuang. (1983). Yurisdiksi Kriminal di Perairan Indonesia yang Berkaitan Dengan Hukum Internasional. Bandung: Alumni.

Lamintang, P.A.F. (1997). Dasar-dasar Hukum Pidana Indonesia. Citra Aditya Bakti: Bandung.

Marpaung, Leden. (2005). Asas Teori Praktek Hukum Pidana. Jakarta: Sinar Grafika.

Murdiyanto, (2003). Mengenal, Memelihara dan Melestarikan Ekosistem Terumbu Karang Proyek Pembangunan Masyarakat Pantai dan Pengelolaan Suberdaya Perikanan. Departemen Kelautan dan Perikanan RI. Jakarta.

Nybakken. (1988). Biologi Laut: Suatu Pendekatan Ekologis. PT. Gramedia: Jakarta.

Purnianti, dkk. (1994). Mashab dan Penggolongan Teori dalam Kriminologi. Bandung: PT. Citra Aditya Bakti.

Prodjodikoro, Wirjono. (2003). Asas-asas Hukum Pidana di Indonesia. Bandung: PT. Refika Aditama.

Sodik, Dikdik Mohamad. (2014). Hukum Luat Internasional. Bandung: PT. Refika Aditama.

Sudirman, Adi. (1982). Wawasan Nusantara. Jakarta: Surya Indah.

Sugiyono, (2011). Metode Penelitian Pendidikan Pendekatan Kuantitatif dan Kualitatif $R \& D$, Bandung: Alfabeta.

Supriharyono. (2007). Pengelolaan Ekosistem Terumbu Karang. Jakarta: Djambatan. 